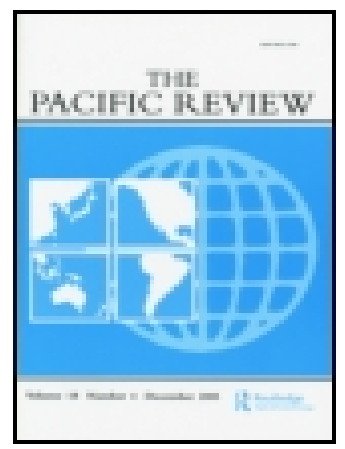

The Pacific Review

ISSN: $0951-2748$ (Print) 1470-1332 (Online) Journal homepage: http://www.tandfonline.com/loi/rpre20

\title{
Framing the Asian infrastructure investment bank: a qualitative analysis of the political debate and media coverage on a China-led multilateral institution
}

\section{Hai Yang \& Baldwin Van Gorp}

To cite this article: Hai Yang \& Baldwin Van Gorp (2018): Framing the Asian infrastructure investment bank: a qualitative analysis of the political debate and media coverage on a China-led multilateral institution, The Pacific Review, DOI: 10.1080/09512748.2018.1512647

To link to this article: https://doi.org/10.1080/09512748.2018.1512647

曲 Published online: 30 Oct 2018.

Submit your article to this journal $[\pi$

Џ Article views: 90

View Crossmark data ־ 


\title{
Framing the Asian infrastructure investment bank: a qualitative analysis of the political debate and media coverage on a China-led multilateral institution
}

\author{
Hai Yang ${ }^{\mathrm{a}}$ (D) and Baldwin Van Gorp ${ }^{\mathrm{b}}$ \\ aLeuven International and European Studies Institute, Faculty of Social Sciences,

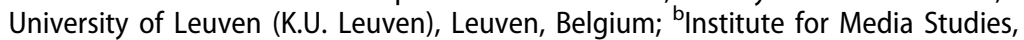 \\ Faculty of Social Sciences, University of Leuven (K.U. Leuven), Leuven, Belgium
}

\begin{abstract}
This qualitative study is designed to identify the frames in the debate on the Asian Infrastructure Investment Bank (AIIB) and analyze the framing by different actors. To that end, it drew insights from framing theory and conducted an in-depth inductive frame analysis based on a representative sample of official documents and news articles. 14 frames (7 frames and 7 counterframes) emerged therefrom. They represent the AIIB debate along six dimensions: China vis-à-vis AllB (Tool, We're all equal), AllB for members (Boon, Bane), AllB versus status quo (Rival, Complement, Winds of change), standards (Made in China, Qualified yes, Up to par), prospects (Off to a good start, Not all roses), and external reactions (Game, Much ado about nothing). Building on the frames identified, the study went further to show how political actors applied frames in their (self-)justificatory discourse, and how media enriched the debate by bringing in frames absent from the official discussions in the political circle. The findings herein not only attest to the contested nature of the AllB and the diverging framing by different actors, but shed some light on the wider discussions on China's evolving relations with the incumbent global system and established powers.
\end{abstract}

KEYWORDS AIIB; frame; frame contest

\section{Introduction}

The Asian Infrastructure Investment Bank (AllB) initiative was unveiled by Chinese President Xi Jinping in October 2013 and lauded as a partial solution to the huge shortfalls in Asian infrastructure finance. Backed early on mostly by small Asian economies (except India) and Middle Eastern countries, the AllB gained traction shortly after the United Kingdom (UK) 'surprised' the United States (US) and its European allies by joining on 
12 March 2015. The world's newest multilateral development bank (MDB) was officially launched in mid-January 2016 with the backing of 56 foreign states other than China. As of late February 2018, the AllB (www.aiib.org) had boasted 84 members worldwide, secured three triple-A credit ratings, and approved 25 projects worth $\$ 4.3$ billion.

Yet the AIIB was contested from the outset, as it was started up by the fast-rising China with a patchy record in development lending. As late as January 2015, members of the Group of Seven (G7) effectively agreed to stay outside in the absence of a consensus (Anderlini, 2015). Suspicious of Beijing's nefarious intention to challenge its primus inter pares status and the new lender's potential to cut corners on common standards and undermine the World Bank (WB) and the Asian Development Bank (ADB), Washington urged allies to shun the China-led proposal (Etzioni, 2016). Ensuing politicization precipitated a vigorous frame contest, with different sides trying to advocate their position and drum up external support. As a politicized multilateral initiative, the AIIB captivated attention beyond state actors. Others, not least news media and international financial institutions (IFIs), equally joined the discussion. Key points of contention include inter alia: what are China's motives behind the initiative? Will China as the largest stakeholder dominate rule-making, decision-making and operation? Will the AllB adopt high standards? Will the new entrant cooperate with or compete against existing MDBs? A suite of diverging or even diametrically opposing answers was given to these questions (see infra). To gain a better understanding of the AllB debate, it is necessary to parse out the embedded frames-defined as particular interpretations of an issue on the part of the framing actors-whereby evaluative judgments are passed and suitable actions proposed (Entman, 1993).

In so doing, the study first and foremost contributes to the emerging research on the AlIB. Extant literature, of different stripes, has focused almost exclusively on the new MDB's governance, innovation, accountability, and prospect (Chin, 2016; Gu, 2017; Humphrey, 2015; Malkin \& Momani, 2016), its potential ramifications for incumbent IFIs, development lending and global economic governance (De Jonge, 2017; Hameiri \& Jones, 2018; Kahler, 2017; Kawai, 2015; Kim \& Kim, 2018; Liao, 2015; Menegazzi, 2017; Reisen, 2015; Strand, Flores, \& Trevathan, 2016; Subacchi, 2015; Wang, 2017; Weaver, 2015), and most of all, the multiplicity of plausible rationale motivating China to propose the bank (Cai, 2018; Callaghan \& Hubbard, 2016; Chan, 2017; Hecan, 2016; Ikenberry \& Lim, 2017; Ren, 2016; Sun, 2015; Wan, 2016; Wilson, 2017; Yang, 2016; Yu, 2017; Zheng \& Liu, 2018). What is largely missing, however, are empirical studies that treat systematically the frame contest over the AIIB, which resulted in a great variety of views and perspectives on the controversial initiative. This study seeks to fill that lacuna. 
The research question at the core of the study is two-fold: what frames were present in the AlIB debate, and relatedly, how did different actors apply them? To address the two-fold question, it draws insights from framing theory to examine the official documents issued by six countriesChina, Singapore, the UK, Australia, the US and Japan, and four IFIs-the AllB, the WB, the ADB and the International Monetary Fund (IMF), as well as the news articles selected from media across the six countries. ${ }^{1}$ After fleshing out the frames, the study then examines how different actors applied the frames in their carefully-constructed political discourse or news content.

An empirically grounded research of the pluralistic and contrasting perspectives on the AIIB also features in the broader debate about China's evolving relationship with status quo powers and the international order. While the rise of China is little disputed, the evidence as to what kind of stance the rising power takes and will take vis-à-vis the incumbent global order is less clear-cut (Breslin, 2013; Zhang, 2017). Depending on the conceptual lens and the issue under consideration, China can be a revisionist state (Mearsheimer, 2010), a status quo power (Johnston, 2003), or a mix of both (Breslin, 2018; Ren, 2015). In this light, different statements on the China-led AllB reflect to some extent divergent assumptions on China's position vis-à-vis the current international system and the divide as to how to best deal with a rising power with an increasingly proactive agenda. Moreover, the AlIB represents the dynamics of change in global economic governance. For the first time since Bretton Woods, an MDB is steered by the emerging powers with China 'sitting at the center of the table, setting the agenda, defining priorities, and rethinking rules' (Chin, 2016, p. 11). A corollary question is how this will affect the liberal economic order? Although frames give no definitive answer, they outline the possible array of perspectives on the issue, thereby enriching the discussions about the relationship between China and established powers and the impact of China's 'emerging institutional statecraft' (Ikenberry \& Lim, 2017) exemplified by the AIIB on the current international order.

The remainder of the article is organized as follows. The first part lays out the key concepts of the strand of framing used in this study. The second part explains the data collection and three-step inductive frame analysis. The third section presents the inductively constructed frame packages, followed by a discussion on the framing by different actors. Finally, some implications are discussed.

\section{Conceptual framework: framing and frame packages}

Framing is a vibrant area of research in media and communication studies (Chong \& Druckman, 2007; D'Angelo, 2002; D'Angelo \& Kuypers, 2010; 
Entman, 1993), and has over time been applied in many other disciplines. As such, definitions and characterizations of frames abound. Gitlin (1980, p. 7) described frames as 'persistent patterns of cognition, interpretation, and presentation, of selection, emphasis and exclusion'. Gamson and Modigliani (1989, p. 3) suggested that a frame be understood as 'a central organizing idea ... for making sense of relevant events, suggesting what is at issue'. Entman (1993, p. 52) postulated that 'to frame is to select some aspects of a perceived reality and make them more salient in a communicating context' (italic original). Reese (2001, p. 11) defined frames as 'organizing principles that are socially shared and persistent over time, that work symbolically to meaningfully structure the social world'.

In terms of operationalization, there are in general two types of frame: generic and issue-specific. The former refers to the frames that 'transcend thematic limitations and can be identified in relation to different topics, some even over time and in different cultural contexts', while the latter concerns the frames that are 'pertinent only to specific topics or events' (De Vreese, 2005, p. 54). But the lines between the two can be blurred, as generic frames can be equally used to frame a specific issue. Generally speaking, generic frames are abstract and often applicable across issues and topics. Typical examples are the five established frames measured by Semetko and Valkenburg (2000)_conflict, human interest, economic consequences, responsibility, and morality. By contrast, issue-specific frames are more concrete because they are inductively derived and thus allow for more nuanced interpretations.

Notwithstanding pluralism in conceptualization and operationalization, frames are generally understood to be organized principles or patterns for making sense of the world, and framing is the process of using frames to present an issue in a given way. Building on the widely accepted understanding and the constructionist paradigm in framing research (Gamson, 1988), Van Gorp (2005, p. 486-487) conceived of a frame as 'a meta-communicative message' that is ingrained in culture and directed from the journalist toward the attentive public. He went on to operationalize frames as interpretive packages, which can be translated into an operational approach to analyzing communicative texts.

Each frame package has a central organizing idea, that is, an implicit cultural phenomenon that displays the package as a whole, for example, an archetype, a myth, a narrative, or a symbol. As part of a shared culture and thus independent of individuals and their cognitive structures (Van Gorp, 2007), culturally embedded frames make an appeal to beliefs that are known to members of society or a given group. Such a cultural resonance in turn facilitates message interpretation, as intended by the sender, on the end of the recipient by 'lend[ing] meaning, coherence, and ready explanations for 
complex issues' (Van Gorp, 2010, p. 88). While frames can be heuristic, they are equally conjured up by framing devices and reasoning devices. Framing devices are manifest textual and visual elements in a text, such as catchphrases, depictions, keywords, metaphors, stereotypes, appeals, contrasts, charts and graphs (Pan \& Kosicki, 1993; Van Gorp, 2010). Reasoning devices form the third and complementary part of a frame package and are directly connected to the four functions of framing-issue definition, casual interpretation, moral evaluation, and solution suggestion (Entman, 1993). Taken together, they form a complete logical chain of reasoning. The power of framing is that these reasoning devices do not have to be explicitly communicated. At the cognitive level, framing devices can trigger a scheme that equals the implicit cultural phenomenon as represented by the core frame. Once the core frame is primed, the human brain will fill in the reasoning gaps associatively.

Before going further, three points need to be emphasized. First, a central function of framing is to promote a particular interpretation of an issue by selecting and prioritizing certain aspects and developments, all the while excluding or downplaying others. Contingent on the frame in use, an issue can be problematic or non-problematic, marginal or consequential. For example, the asylum issue can be covered through the frame of victims or intruders (Van Gorp, 2005). Second, it is useful to differentiate advocacy frames from news frames. Political actors compete in frame contests by sponsoring certain interpretations of a situation or an issue (advocacy frames); most news media, while replying on political actors as sources, do not simply passing on messages provided by these actors but propose alternative interpretations (news frames) to shape the public debate (Brüggemann, 2014). Third, the use of frames is by no means static but evolves over time. As the social and political context changes, frames can ebb and flow in prominence (Gamson \& Modigliani, 1989).

\section{Data collection and analysis}

\section{Sample}

To assemble a representative sample of political discourse and news content, the study zooms in on six countries with (slightly) different positions vis-à-vis the AIIB: China, Singapore, the UK, Australia, the US, and Japan. China was the principal legitimating force of the AlIB initiative and is now the largest stakeholder of the new institution. Singapore was one of the early 21 signatories of the Memorandum of Understanding (MoU) on Establishing the AIIB on 24 October 2014, when major economies were still rather reticent about the proposal. The UK was the first G7 member to participate in March 2015 against the warning of Washington and its own Foreign Office (Anderlini, 2015). Shortly thereafter, Australia shifted its earlier 
cautious attitude and followed suit. The US was skeptical and urged allies to stay outside. But after a host of countries joined, it extended a qualified welcome to the AllB, albeit showing no desire to join. Japan, in lockstep with the US, expressed reservations about the standards of the Chinabacked bank. Still, Asia's second largest economy and the ADB's largest stakeholder signaled willingness to consider membership provided certain conditions are met. Overall, the selection of the six countries is in line with the diverse case selection paradigm (Seawright \& Gerring, 2008), with a view to ensuring variation and increasing the likelihood of finding all the frames.

The inclusion of news content is necessary because media were an indispensable part of the frame contest. The crystallization of the China-US disagreement on the AllB following the UK's decision triggered a huge news wave. A considerable number of news stories were written on the AllB, which reinforced or challenged messages sent out by political actors. More specifically, media content from the afore-mentioned six countries were chosen. The reason is that difference in the governmental position across the six countries on the AllB is expected to be reflected, at least partially, in their media coverage, as 'a prevalence of distinct national logics in news production should yield observable differences in frames present in the news across countries' (Wessler, Wozniak, Hofer, \& Lück, 2016, p. 425).

In addition, the study includes official discourse of the AllB, the WB, the $A D B$, and the IMF. As a new MDB initiated by China, the AllB faced a constant need to legitimate itself, both to (potential) members and in relative to its established peers. The other three institutions represent the global financial establishment that the AllB is supposed to challenge or complement. As such, their representatives were often asked to weigh in on the AllB. Their comments were widely quoted in media and used by states to reinforce their argument.

To be more concrete, all the publicly available official documents (e.g. statements, speeches, press releases) relating to the AlIB issued by the six countries and the four institutions were included; as for news articles, three newspapers (two daily broadsheet newspapers and one financial newspaper) were selected from each of the six countries. The main selection criterion was the intensity of coverage, all the while ensuring the diversity of political position when necessary. This, however, resulted in the inclusion of only elite media. ${ }^{2}$ From selected news outlets, all the texts containing 'Asian Infrastructure Investment Bank' or 'AllB' were gathered and reviewed. Given the study's focus on the AllB framing, only articles with substantial coverage of the subject were included. Altogether, the sample counts 240 official documents and 1,017 news articles, ${ }^{3}$ covering the time period from October 2013-when China unveiled the AllB initiative, till January 2018-about two years after the AllB's official launch. Detailed breakdown and sources of the sample are shown in the Appendix 1 . 


\section{Inductive frame analysis}

To identify the embedded frames and construct a matrix of frame packages on the AlIB, the study conducted an in-depth inductive analysis. It manually coded the data following the three-step method suggested by Van Gorp (2010, p. 93-97). The three steps-thematic coding, axial coding, and selective coding-based on the systematic methodology of grounded theory (Strauss \& Corbin, 1990), were taken in parallel and iteratively. Thematic coding is to review texts with no hypotheses derived from extant scholarship and to code repeated ideas. The purpose is to identify and collect a comprehensive list of text excerpts that discuss a given topic from different perspectives by different parties. In this study, all the keywords and phrases relating to the AllB were coded. For instance, why China started up the AllB? What will be the relationship between the new bank with other MDBs? What kind of standards will the AllB adopt? How has the newcomer fared thus far and what will become of it in the near future?

The second step is axial coding. It entails disaggregating the coded data to identify recurring patterns and cluster them to overarching categories. Building on the first step, it seeks to uncover the embedded frames in the text fragments, all the while trying conscientiously to overcome potential overlaps between them. For instance, coded elements on the first question were first sorted under 'China's motivations' before being further divided into 'self-interest' or 'provision of a much-needed public good', those on the second question were first put under 'inter-institutional dynamics' and further differentiated into 'complementarity', 'rivalry' and 'legitimate change', those centering on the issue of 'standards' were split into 'low standards', 'acceptance conditioned on meeting certain standards' and 'up to standard', and those discussing the AllB's performance/prospects were sub-grouped into 'substantial progress' and 'lackluster performance'. After this, only a manageable number of significant codes were retained. The last step is selective coding, which refines the codes and organize them around core categories (i.e. frames) before drawing out the complete frame packages by adding typical framing devices and reasoning devices. Following through on one of the foregoing examples-China set up the AllB out of self-interest, the final step would require pinpointing a condensed concept, identifying specific words and formulations, and articulating the four-step reasoning. Which concept can aptly evoke the idea of China using the AllB for narrow self-interests? What are the reasons for such an argument? What is the moral judgment? What are the consequences? And finally, what can be done about it?

The three steps culminated in a matrix of interpretative frame packages. For the inductive frame analysis, the entire corpus of official documents and news articles was minutely read and parsed. Results are shown in a 
single overview, without immediately indicating which actor used each of the frames-an aspect that will be addressed in the following discussion.

\section{Findings: seven frames and seven counterframes}

Altogether, 14 frames were identified. They look at the AllB debate along six dimensions (Table 1). In what follows, each frame is articulated and contextualized with quotes directly taken from the sample. It should be noted that selected quotes, albeit emblematic, do not reflect the frame package in its entirety. ${ }^{4}$ The 14 frame packages with representative framing devices and reasoning devices are shown in Appendix 2.

\section{A. Tool}

This frame regards the AllB as a tool designed to advance Chinese interests. It dwells on Beijing's hidden motives behind the project and its ability to exercise de facto veto as a function of shareholding, as well as the antecedent of China leveraging economic power for political ends and of IFls doing the bidding of their leading stakeholders. Hence, the AllB is 'a financial institution by China and for China' (Japan Times, 2015b). It is envisaged that China will exploit the Beijing-headquartered bank to pursue narrow economic and geopolitical goals, such as financing the Belt and Road Initiative (BRI). The following remark is a prime example of this frame: 'China would use the bank for its own pet projects in Asia and try to knit together the poorer countries of Southeast and Central Asia into an economic sphere of influence' (Perlez, 2015).

\section{B. We're all equal}

As the counterframe to Tool, this frame maintains that the AllB is 'a global financial institution that believes in equality' (Zhang, 2016). It has four main aspects. First, as regards rule-making and decision-making, China has built mutual trust with others by 'collective consultation and making decisions on democratic approaches' and it has no intention to exercise veto ( $\mathrm{Fu}$, 2016). All the founding members had the right to shape the AllB's rules

Table 1. An overview of frames on the AllB.

\begin{tabular}{|c|c|c|}
\hline Dimensions & Frame & Counterframe \\
\hline China vis-à-vis AllB & Tool & We're all equal \\
\hline$A l l B$ versus status quo & Rival & $\begin{array}{l}\text { Complement } \\
\text { Winds of change }\end{array}$ \\
\hline AllB for members & Bane & Boon \\
\hline Standards & $\begin{array}{l}\text { Made in China } \\
\text { Qualified yes }\end{array}$ & Up to par \\
\hline Prospects & Not all roses & Off to a good start \\
\hline External reactions & Game & Much ado about nothing \\
\hline
\end{tabular}


through the multilateral negotiations (Chief Negotiators' Meetings) leading up to the bank's launch. Second, with respect to membership, the AllB is and will always stay open to all, including perceived strategic rivals of China, countries embroiled in maritime disputes with China, non-regional powers, and non-sovereign economies. Third, the bank advocates universal procurement and universal recruitment, equally treating companies and nationals of non-AllB countries. ${ }^{5}$ Fourth, the AllB distances itself from the Chinese leadership and the BRI (Kim, 2017), so as to placate concerns that it is a crude Chinese foreign-policy instrument.

\section{A. Rival}

This frame argues that the AIIB is writ large 'a rival bank duplicating and potentially undercutting' its established peers (Higgins \& Sanger, 2015). The unease stems not only from the bank's mandate to fund large infrastructure projects in Asia-identical or at a minimum similar to the core business of the WB and the $A D B$, but with fewer conditions and laxer loan approval procedures. More broadly, the pronounced 'assertive' turn in Chinese foreign policy since Xi Jinping came to power seems to confirm this reasoning. The launch of several high-profile moves in parallel to the AIIB, notably the BRI and the New Development Bank (NDB), ${ }^{6}$ is emblematic of China's increasing economic wherewithal and status-seeking ambitions. The AllB, for that matter, is one of the vanguards and raises the specter of Beijing drafting a parallel economic system of its own to compete against and fragment the current one (Funabashi, 2014). The AIIB, along with the NDB, is therefore regarded as 'perhaps the biggest challenge yet mounted to the Bretton Woods international financial architecture' (Donnan, 2015).

\section{B. Complement}

This frame is the counterframe of Rival. It sees the AllB as a constructive complement. It is backed first by China's assurance on the ancillary role of the AllB and by the bank's hitherto record of co-financing projects with alleged competitors. As Jin Liqun said, '[AIIB] has no intention to challenge the international financial order or to pose a threat to other multilateral development banks. The bank is working seamlessly with international institutions ... to cofinance infrastructure projects' (Li, 2016). Second, the establishment of regional MDBs in the past like the ADB did not undermine established institutions but reinforced them. Third, the bank carves out a distinct niche by bankrolling Asia's infrastructure, an area with massive needs that can accommodate multiple players. Last comes its priority on physical infrastructure, which supposedly differs from that of the WB and 
the ADB on social-oriented lending and poverty alleviation. As then Chinese finance minister Lou Jiwei said, 'in view of the huge financing gap in the infrastructure sector, due to differentiated mandates and priorities, the relationship between the AIIB and existing MDBs will be complementary and cooperative rather than competitive' (China Daily, 2014).

\section{C. Winds of change}

This frame is the second counterframe of Rival. It juxtaposes the AllB with the problematic status quo and views it as a force bringing about positive changes. It has three main prongs. First, the AlIB materialized due in part to the deepening frustration of the world's second largest economy toward its under-representation in the anachronistic Bretton Woods system and the foot-dragging of US Congress to approve the 2010 IMF reform. By giving emerging countries a bigger voice, the AllB helps 'make the global economic governance system more just, equitable and effective' (Xi, 2016). Second, existing MDBs, not least the WB and the $A D B$, have been mired in many structural problems, for example, being too risk-averse and bureaucratic. Featuring a lean bureaucracy, the AllB is slated to be 'quicker and more efficient' (Piling, 2015). The new bank also differs from other MDBs by not imposing ideology and free-market policies (Yang, 2015). Third, the multilateral AIIB marks a break on the part of China with 'a decade of aggressive bilateral lending' (Hornby, 2015). Beijing's attempt at 'creating a new international institution even at the cost of bypassing the existing ones, was on balance a positive development' (Financial Times, 2016).

\section{A. Bane}

The frame surmises that the AlIB membership, enticing as it may seem, can have damaging consequences. It first questions whether the presumed payoffs, if any, are worth the potential financial costs. The capital required for membership adds to the heavy debt of governments, notably for big economies, since financial contributions are proportional to economic size. Also, large contribution is unlikely to translate into guaranteed influence in the AIIB due to China's oversized presence. Second, AllB membership can have outright detrimental effects on members in certain cases. Some under-developed Asian nations like Myanmar are already struggling with high repayments and continuing to borrow from the AllB at potentially high-interest rates (Nikkei Asian Review, 2015b), will increase debt dependency. Worse, being part of the AIIB can come at the cost of politicalstrategic interests. For example, AIIB membership might corrode Taiwan's 'sovereignty' (Wu, 2015), 'hurt [Japan's] ties with the United States' (Japan Times, 2015a), and 'further weaken the ASEAN community' (Tsui, 2015). 


\section{B. Boon}

This frame is directly opposed to the preceding one. It makes the case that the AlIB will bring concrete benefits. First, it considers the AIIB as 'a timely initiative' to address the massive infrastructure needs (Singapore Ministry of Finance, 2015b). ${ }^{7}$ Multilateral lending from the WB and the ADB has been and continues to be insufficient, and the private sector is disinclined to fund risky infrastructure projects. The AllB will 'boost investment to support infrastructure development in Asia ... serve to channel more resources, particularly private investment, into infrastructure projects to promote regional connectivity and economic integration' (Xi, 2016). Also, infrastructure building in fast-growing Asia creates 'an unrivalled opportunity' for businesses (UK Treasury, 2015a). Besides, the healthy competition brought by the AIIB will energize established MDBs to boost lending efficiency and capacity, ultimately to the benefit of borrowing countries. Tellingly, even before the AllB opened for business, the WB and the ADB had already stepped up their infrastructure financing in Asia (Piling, 2015).

\section{A. Made in China}

This frame presumes that the AllB, cast from the problematic Chinese mold, will fall short of common standards. The bank was a brainchild of China and will be steered by its chief architect, as there is no resident board and an erstwhile Chinese official was handpicked by Beijing to head the management team. Meanwhile, China is known as an outlier in development cooperation, riding roughshod over international standards and prevailing practices in its bilateral lending. ${ }^{8}$ As lamented here, 'if China's exploitative record in the poorest countries of Africa is anything to go by, that could bring with it high-level corruption, environmental damage and brutality towards anyone who gets in the way' (Weyer, 2015). As such, skeptics were concerned about the AllB's standards (US Treasury, 2015a). Some went further to dismiss the China-led bank as 'Beijing mercantilism writ large' (Financial Times, 2015), which could 'erode already strained international lending standards of transparency, creditworthiness, environmental sustainability ... [and] labor and human rights that took decades to put in place' (New York Times, 2015).

\section{B. Qualified yes}

This frame argues for a qualified welcome/acceptance of the AllB. While recognizing the utility of the $A$ IIB, it notes that the initiative remains underspecified. Of particular relevance is the all-important issue of standards. Hence it is reasonable to attach conditions to potential 
membership, approval or cooperation. It manifests in three variants. First, some governments put conditions on participation. For instance, Australia outlined several conditions before signing on the MoU (Massola, 2015), and would formally decide to become a member only if these conditions are met. Second, for countries not actively considering membership, the AllB would be welcomed provided it has high governance and lending standards (US Treasury, 2015b). Third, for established MDBs, cooperation with the AllB is contingent on whether the new entrant can comply with their standards (Nikkei Asian Review, 2015a).

\section{C. Up to par}

Contrary to the two preceding frames, this frame maintains that the AllB has respectable standards. First, rigorous multilateral negotiations leading up to the AIIB's launch ensured that the AIIB would be 'a truly international, rule-based and high-standard institution in all aspects' (Xi, 2016). Substantively, the new bank has committed itself to cultivating a modus operanti of 'clean, lean, green' and funding projects that are 'financially, environmentally and socially sustainable' (Li \& Zhang, 2016). Second, the optimism was bolstered by the participation of advanced economies, which vowed to ensure that the AIIB embodies best standards (Higgins \& Sanger, 2015; UK Treasury, 2015b), and by the AllB's partnerships with established MDBs, which 'demonstrate a commitment to the highest standards' (Fackler, 2015). Third, external scrutiny is likely to play a role. As stated here, 'with all the criticism and suspicion that this all a big cover for Chinese power, Beijing will lean over backwards to adhere to best practice ... They will make sure they are holier than the Pope' (Khan, 2015).

\section{A. Not all roses}

This frame brings to light the teething problems of the AIIB and the tough times it faces going forward. Among others, two problems and two challenges worth mentioning. First, Beijing's prevarication over and rejection of Taiwan's bid to become a founding member of the AIIB was thought to be driven by political consideration, which 'could portend how Beijing will run the new institution' (Hsu, 2015). Second, the new bank has yet to rule out the possibility of funding coal projects, subjecting itself to criticism that 'it is exporting pollution and undermining the best practices to which Mr. Jin aspires' (Kynge, 2017). In addition to the problems, it is expected that the AllB will face daunting challenges. The first is the self-evident collective action problem. With such diverse stakeholdership, 'the internal dynamics and competing interests are proving challenging to manage' (Perlez, 2015). 
The second is that the bank has to make good on its promise to streamline bureaucracy all the while keeping due diligence. For some, however, 'bureaucracy is a necessary evil in consensus-building and in ensuring better-quality projects' (Magnier, 2015).

\section{B. Off to a good start}

As the counterframe of Not all roses, this frame zooms in on the aspects along which the AllB has shown promise. First, broad and broadening membership has substantiated the promising prospects of the AllB. After the bank's membership expanded to 80, President Jin (2017) said, 'broad support from both our regional and non-regional membership manifests a firm confidence in AllB'. The second point concerns the efficient institution building. As said here, the AllB was launched 'just six months after articles of agreement were signed ... and 26 months after President Xi Jinping proposed it' (Zheng, 2016). Third, the bank has performed well since opening, building a 'very strong business profile' and an 'extremely strong financial profile' (AllB, 2017). The fourth aspect touches on the respectability of the management. President Jin was extolled as 'bright, well-connected and polished' (Anderlini, 2015) and five Vice-Presidents as 'an exceptionally strong and committed group' (Asian Infrastructure Investment Bank, 2016). The fifth dimension is on the bank's strong creditworthiness, bolstered by (large) members' commitments and validated by the three triple-A ratings (Asian Infrastructure Investment Bank, 2017). Taken together, it is ever clearer that the AIIB is off to a good start and will likely have a promising future.

\section{A. Game}

This frame depicts a zero-sum strategic game characterized by winning and losing. Specifically, it treats the AllB as an example of the rivalry between China and the US (and to a much lesser extent, Japan). The bank was construed as part of China's gambit to parry the US rebalancing to the AsiaPacific (Perlez, 2014). Also, China can diminish the influence of the US (and Japan) in the WB and the ADB through the AllB. Rooted in such strategic considerations, the Obama administration put pressure on its allies and forced them to 'make a fatal choice between the US and China that none wished to make' (Evans-Pritchard, 2015), since it was between 'American might' and 'Chinese cash' (Feldman, 2015). The UK's decision to 'break ranks' was the turning point (Anderlini, 2015), prompting a rush by US allies in Europe and Asia-Pacific to follow. This signaled that Washington's effort to 'delegitimize and marginalize the AlIB has failed and failed spectacularly' (Drezner, 2015). Through the prism of a zero-sum calculus, the AllB episode was a success for Beijing and a setback for Washington (and Tokyo). 


\section{B. Much ado about nothing}

This frame deems the AllB as something of little significance, and thus, there is no need to overreact. It contrasts the dramatic reaction to the AllB with its extremely modest capital and as yet unclear prospect. The fledgling's lending scale is merely 'a drop in the ocean' compared to that of the WB, the ADB, and China's state policy banks (Kynge, 2017), and it remains unclear 'how much of a dent the new bank could make in the region's multi-trillion-dollar needs for roads, dams, bridges and ports' (Washington Post, 2015). 'For now, for all the excited chatter, the AllB is an institution laden with symbolic value, and little else' (Denyer, 2015). Also, the success of the up-start is not guaranteed, as 'there is a long list of international institutions that were created with much fanfare only to be relegated to the footnotes of world history' (Voeten, 2015). It is therefore much of an exaggeration that the AllB will result in the diminution of American leadership and fragmentation of global economic governance. Rather, it is a 'small-potato issue' (Pennington, 2015) blown out of proportion by the US's ill-considered machinations and the media hype. A proper response is to let it 'rise or fall on its own merits' (Evans-Pritchard, 2015).

\section{Discussion: framing by actors}

After offering a commanding view of the multiple and contrasting interpretations on the AllB, it is needful to take one step further and study how different actors actually applied the reconstructed frames. Addressing the 'who applied what' question will allow us to draw a fine line between advocacy frames sponsored by political actors and news frames proposed by media.

\section{States}

The selected six state governments were prominent actors in the framing contest on the AllB. They strategically sent out messages with frames-or some combinations thereof-to promote their preferred interpretations and rationalize their official ${ }^{9}$ position vis-à-vis the AllB. China was the principal legitimating actor and is now the largest stakeholder of the newly-established bank. As showcased in the views expressed by Chinese leadership (Lou, 2015; Xi, 2016) and statements issued by Chinese Finance Ministry (www.mof.gov.cn), China was persistent in stressing the new bank's raison d'être-its potential benefits for Asia and members (Boon) and substantive contribution to ameliorating international economic governance (Winds of change), cooperative stance vis-à-vis established MDBs (Complement), commitment to multilateralism, equality, and openness (We're all equal), resolve to institute high standards (Up to par), 
broadening membership, expanding operations, and strong creditworthiness (Off to a good start). Simply put, China endorsed all the nonproblematizing frames.

Singapore was one of the 21 countries that signed the MoU in October 2014 when major economies were still shunning the AllB initiative. To justify early participation, the city-state framed the AllB as 'a positive development which will help meet the immense infrastructure needs in Asia' (Boon) and stressed its desire to work with others to build the AllB as 'a resilient multilateral institution, complementing and drawing on best practices of existing players' (Up to par) (Singapore Ministry of Finance, 2014). This positive position was reaffirmed upon its signing of the Articles of Agreement (AoA) (Singapore Ministry of Finance, 2015a). While seeking parliamentary approval of the AoA, the government argued further for the AllB's importance for Singapore as an international financial hub (Boon) and its role in strengthening the existing international financial architecture (Complement), and expressed strong confidence in the new institution, as it had enjoyed 'good support around the world' (Off to a good start) (Singapore Ministry of Finance, 2015b).

The UK was the first G7 member to apply for AllB founding membership, 'surprising' the US and its European partners. London gave three reasons for its decision (UK Treasury, 2015a). First, the AllB is mandated to 'support access to finance for infrastructure projects across Asia ... to boost investment across a range of sectors' (Boon) and therefore 'complement the work already done in the region by existing Multilateral Development Banks' (Complement). Second, joining at the founding phase allows the UK to 'play a key role in ensuring that the AIIB embodies the best standards in accountability, transparency and governance' (Up to par). Third, AllB membership is 'an unrivalled opportunity for the UK and Asia to invest and grow together' (Boon). The three-fold reasoning was reiterated in the statements upon the UK's signing and ratification of the AoA ( UK Treasury, 2015b, 2015c)

Australia, caught between China and the US, adopted a cautious position early on. While seeing a real added value for the AllB to meet Asian infrastructure needs, Canberra raised major concerns about standards and thus the need to put conditions on membership (Qualified yes). Even in the statement announcing Australia's intent to sign on the MoU, it was noted that 'key matters to be resolved before Australia considers joining the AllB include the Bank's Board of Directors having authority over key investment decisions, and that no one country control the bank' (Australia Prime Minister and Cabinet, 2015). After formally signing up, Canberra took up a stance quite similar to that of London. The statement announcing Australia's formal decision to become a founding member (Australia Treasury, 2015) underlined the AllB's role in closing the funding gap and in so doing 
bringing trade and investment opportunities for Australian businesses (Boon), and the bank's high governance standards (Up to par) that ensure all members are involved in the direction and decision-making (We're all equal).

The US was the foremost skeptic. While acknowledging the need for more infrastructure financing, the US repeatedly spoke of its reservations about the AllB's standards (Made in China). When commenting on the AIIB in March 2015, then US Treasury Secretary Jack Lew stated that 'our concern has always been ... will it adhere to the kinds of high standards that the international financial institutions have developed? Will it protect the rights of workers, the environment, deal with corruption issues appropriately?' (US Treasury, 2015a). Equally, Washington often qualified its approval of new additions, including the AIIB, to the international financial order (Qualified yes). That is, it would only put out the welcome mat 'provided that these additions complement existing international financial institutions and share the international community's strong commitment to genuine multilateral decision making and ever-improving lending standards and safeguards' (US Treasury, 2015b).

Japan largely sided with the US in doubting the AllB's ability to adopt international standards (Made in China) and maintaining a cautious stance on AIIB membership (Qualified yes). While not ruling out eventual participation, Tokyo emphasized the need for the AlIB to clear doubt about governance and lending standards before it can take a formal decision. In April 2015, Japanese State Minister Kiuchi Minoru outlined two conditions: 'First, it must be clarified whether or not it is possible to establish fair governance, and second, whether or not carrying out lending that ignores debt sustainability would not inflict harm on other creditors' (Japanese Foreign Ministry, 2015). It has maintained such a position up till now.

As made clear in the foregoing analysis, the most salient point of contention in the official discussions of the six states centers on standards-or rather the lack thereof. While AlIB members underscores that the AlIB would embody good practices and lending standards thanks to the broad support and participation worldwide, skeptics justified their abstention or reluctance to commit by camping on the possibility of the AlIB having low standards.

\section{IFIs}

The AIIB, as a newcomer to the international financial architecture, faced difficult questions on many fronts. Many challenges its raison d'être, standards, and relationship with China. Its framing, unsurprisingly, was similar to that of its initiator China (see supra). Even so, there was one noticeable difference. Official discourse of the AlIB made little, if any, 
reference to the Winds of change frame. This is understandable, since using such a frame would not only put other IFIs in an awkward position, but also set the bar even higher for itself.

Incumbent IFIs, represented by the WB, the IMF and the ADB, equally participated in the AllB debate. These established institutions, supposedly in direct competition with the new bank, were nonetheless arguing in favor of its creation, at least officially. When asked to comment on the AllB, IFI representatives pointed to the huge need for infrastructure in Asia and beyond to drive economic growth (Boon) and proposed to cooperate with the 'new kid on the block' through co-financing (Complement). As WB President Jim Yong Kim (2015) stated approvingly, the new lender 'has great potential to help Asia build power plants, roads, bridges, schools, and clinics that will create jobs and boost economies. When it comes to promoting development in low-and middle-income countries, there's no reason for institutions to be rivals'. IMF Managing Director Christine Lagarde (2015) chimed in, stating that 'the proposal to have a completely dedicated institution that will focus on infrastructure on a regional basis is actually an attractive proposition ... So, that is a most welcome institution and one with which the IMF certainly is planning to cooperate with'.

\section{Media}

In respect of framing by news media, two caveats bear mentioning before proceeding. First, the qualitative study does not seek to provide a countryby-country analysis of media frame use nor to illustrate how the use of frames by media evolved over time-both aspects merit to be accounted for in their own right, but to identify the frames put forward by media other than those sponsored by states and IFIs. Second, it is imperative to draw a distinction between state-owned media and independent media. The former tends to engage in 'frame sending' by passively passing on interpretations of other actors without providing alternative perspectives or adding more nuances; the latter is likely to pursue 'frame setting' by actively proposing their own interpretations (Brüggemann, 2014, p. 62).

Chinese state media, known as the mouthpiece of the party and the government, accepted uncritically all the non-problematizing frames on the AllB (Boon, Complement, Winds of change, We're all equal, Up to par, Off to a good start) articulated by Chinese officialdom, all the while excluding problematizing ones (Tool, Rival, Bane, Made in China). They did, however, deviate slightly from China's official position by making occasional references to the major challenges the AllB faces (Not all roses) (e.g. Fu, 2017), and the AllB as an example of the lingering cold-war mentality of the US and its attempt to contain China's rise (Game) (e.g. Chen, 2015). 
By contrast, selected news media in the other five states almost invariably went beyond 'framing sending'. Of course, they still had to rely on their sources, especially representatives of the governments and IFIs, for frames of reference (Boon, Complement, Made in China, Qualified Yes, Up to par, Off to a good start). Nevertheless, they put forward competing interpretations of the AIIB as an alternative or a counterbalance to the official discussions, often by enlisting the help of anonymous officials, other media, academics and think-tankers. In general, media are proved to be prone to covering politics via a strategic game frame characterized by winning and losing (Aalberg, Strömbäck, \& De Vreese, 2012; Lawrence, 2000). In particular, media in these five countries contributed, albeit to varying degrees, to portraying the AllB as a manifestation of Chinese-American competition (Game) (e.g. Financial Times, 2015; Washington Post, 2015) and an insecure overacting US (Much ado about nothing) (e.g. Voeten, 2015), a force jostling for dominance with the WB and the ADB (Rival) (e.g. Nussey, 2016), and a crude instrument serving Chinese foreign-policy interests (Tool) (e.g. Japan Times, 2015b) at the expense of others (Bane) (e.g. Tsui, 2015).

\section{Conclusions}

This study is designed to identify the frames in the AllB debate and analyze the use thereof by different actors. To that end, it conducted an inductive frame analysis of the political discourse and news content on the Chinabacked multilateral institution. 14 frames emerged therefrom, which look at the AIIB along six dimensions: China vis-à-vis AlIB (Tool, We're all equal), AlIB for members (Boon, Bane), AllB versus status quo (Rival, Complement, Winds of change), standards (Made in China, Qualified yes, Up to par), prospects (Off to a good start, Not all roses), and external reactions (Game, Much ado about nothing). Subsequently, the research showcased how political actors (states and IFIs) applied frames in their (self-)justificatory discourse, and how news media enriched the debate by bringing in frames absent from the official discussions in the political realm.

The findings herein are relevant for our understanding of the AllB in particular and China's evolving relations with the current international system and established powers in general. First, the juxtaposition of frames and counterframes, resulting from the framing contest between different political actors and between the political and media circles, reveals the contested nature of the AllB. On any fair account, diverging views and perspectives on the bank are rooted in its distinct features: ambiguous, China-led, 'new kid on the block', and politicized economic project. These features enable actors to produce evidence, sometimes even diametrically opposed to each other, to justify their stance on the AllB. The overwhelmingly positive framing 
of the AllB by the Chinese government and state media was designed to legitimate the new institution and discredit rivaling claims. Among international political actors, a clear divide emerged on the AllB issue. There was the fairly positive framing by governments of the UK and Australia-eager to capitalize on the business opportunities provided by the AllB and closer ties with China, as well as representatives of established IFIs-keen to stress 'the more the merrier' logic in global finance. This stood in contrast with the more alarmist tone taken by the US and Japan, two actors arguably having the most to lose as the new bank rumbled to life. As for the selected foreign media, their efforts to propose a set of game-related frames (Game, Rival, Tool, Bane) attested to their proven record of covering (international) politics from a strategic game perspective.

Second, as an ever-present element of the framing contest, the debate on standards evinces the continuous contestation between the traditional donor club represented by the US, Japan and Europe, and emerging donors such as China. The former expressed concerns that the China-instigated MDB would not be up to international common standards given China's track record in bilateral lending and therefore the need to repeatedly stress the importance of standards (Made in China, Qualified yes). Beijing was quick to dismiss such concerns as misguided, noting that the AllB is committed to respectable standards and practices (Up to par), but not Western ones that disregard development experiences of developing countries like China (Winds of change). Up till now, the AllB has treaded a cautious path to avoid controversy on standards. Nevertheless, unless China adequately addresses the problems often associated with its bilateral development aid and investments overseas, such a debate is likely to resurface every time China proposes a multilateral economic initiative. In fact, remarkably similar discussions on standards have already been unfolding for the BRI, with major powers (including AIIB members such as the UK, Germany, France) doubting whether the BRI will respect international standards on transparency, procurement, and social-environmental standards (Prasad, 2018).

Third, some frames (Rival, Complement, Winds of change, Tool, Game) situate the AIIB in the broader context of China's position on the global economic architecture underpinned by existing IFIs and led by status quo powers. In light of the AllB's representativeness and salience in China's growing institution-building behavior (Ren, 2016), the views and perspectives uncovered in this framing exercise are likely to characterize more generally debates on similar multilateral moves backed by Beijing (e.g. BRI, NDB) and Chinese increasingly active foreign policy. In broad terms, a revisionist perspective will probably apply frames such as Rival, Tool and Game to foreground the ulterior motive of the unsatisfied rising power to challenge existing IFIs and hegemon, as well as the reflexive antagonism of 
the latter in face of such an actor as China. Arguments on China as a status quo power are invariably connected to Complement, and sometimes, Winds of change. They note that even with new institutional initiatives, Beijing still values cooperation with established IFIs and powers and follows, admittedly selectively, international norms. A mixed view, as the term suggests, may take recourse to all these frames. It maintains that China has accepted (or even embraced) multilateral cooperation and governance overall, but it is dissatisfied with the unfair distribution of power and the rules of game in the incumbent global system. Hence, it takes a reformist position by proposing complementary alternatives. As it stands right now, the dynamic AllB debate, contextualized in a diverse array of frames, gives ammunition to all these perspectives, depending on the aspect under study and the evidence drawn.

Fourth, the AlIB discussions bring to relief an ambivalent attitude toward the rise of China. Countries in many quarters saw the AllB as an amalgam of an opportunity to forge closer economic ties with fast-growing China (and Asia) and benefit therefrom, and a tell-tale sign of the rising power's growing ambitions to boost its profile and undercut the US-led liberal economic order-an aspect understandably not reflected in the official discourse. This explains, at least partly, their (early) oscillation between engagement/accommodation and suspicion/containment. The quandary was particularly acute for China's neighbors-wanting Chinese investments (Boon) and yet fearful about political implications (Bane), and major US partners-facing a hard choice between forging close economic-commercial links with Beijing and honoring long-standing political-strategic commitments to Washington (Game). To the dismay of China alarmists and the US, many chose economics over solidarity. Of course, their participation was further facilitated by China's high-flying rhetoric on its benign intentions and commitments to multilateralism (We're all equal, Complement) and high lending standards (Up to par).

Informative as it is, this qualitative study is only the first step toward a full-blown frame analysis. A following quantitative phase with a larger sample is highly desirable. From a methodological point of view, a quantitative analysis is sensible in that it helps to ascertain how and the extent to which the inductively reconstructed frames were applied (frame frequency, intensity, co-occurrence, evolution, and so forth). As for the research on the AllB, it would be illuminating to carry out a granular, country-by-country analysis of framing by media. This will not only allow a systematic cross-country comparison, but also serve as a way of gauging how China's legitimacy claims, as reflected in its state media, were received by leading foreign media.

\section{Notes}

1. The selection of the six countries and four IFIs is discussed in the method section. 
2. A keyword ('Asian Infrastructure Investment Bank' and 'AllB') of databases (LexisNexis and ProQuest) and websites shows that elite media dominated the AllB news discourse and tabloid newspapers coverage was almost non-existent.

3. On the selection of news articles, two caveats are in order. First, articles were taken both from databases and websites. The latter was preferred in cases where databases do not include articles from a specific source, and where the number of online articles was much higher than that found in databases (for example, Nikkei Asian Review published 168 AllB-focused articles online but only 48 were found in LexisNexis). All the online articles were replicated separately and are available upon request. Second, the sample gathered all the AllB-focused articles found in selected news media, which nevertheless displayed a rather uneven distribution. However, domination of articles from a single source (e.g. Nikkei Asian Review in Japan) does not bias the findings of the inductive frame analysis wherein frame frequency is not analyzed.

4. The complete datasheet resulting from inductive coding with core elements and typical statements is available upon request.

5. The advocate of universal procurement and universal recruitment can be equally applied to the Winds of change frame if used to stress the AllB's difference form other MDBs.

6. The NDB is a joint project of Brazil, Russia, India, China and South Africa.

7. The 'funding gap' argument can be used for the Complement frame as well.

8. The 'low standard' argument is equally applicable to the Rivalry frame if used to stress the disruptive impact of a sub-standard AlIB on Bretton Woods institutions.

9. Official position of a state government is not to be confounded with its position in close-door diplomatic exchanges.

\section{Disclosure statement}

No potential conflict of interest was reported by the author.

\section{Notes on contributors}

Hai Yang is a doctoral candidate at the Leuven International and European Studies (LINES) in KU Leuven. His research interests include the newly-established Asian Infrastructure Investment Bank, China's legitimation of its multilateral initiatives, and Chinese foreign policy in general. His recent works include 'The Asian Infrastructure Investment Bank and status-seeking: China's foray into global economic governance' published in Chinese Political Science Review, and 'Time to up the game? Middle Eastern security and Chinese strategic involvement' published in Asia Europe Journal.

Baldwin Van Gorp is a professor of journalism and communications management at the Institute for Media Studies in KU Leuven. His research mainly focuses on framing: conceptualization, methodologies, practical applicability, and effects. $\mathrm{He}$ has applied framing to a variety of topics, including refugees, Europe, psychological disorders, dementia, and child poverty. He has previously published articles in Journal of Communication, European Journal of Communication, Journalism, Journalism Practice, Social Science \& Medicine, among others.

\section{ORCID}

Hai Yang (D) http://orcid.org/0000-0002-9719-1813

\section{References}

Aalberg, T., Strömbäck, J., \& De Vreese, C. H. (2012). The framing of politics as strategy and game: A review of concepts, operationalizations and key findings. Journalism, 13(2), 162-178. 
Anderlini, J. (2015, March 26). UK move to join China-led bank a surprise even to Beijing. Financial Times. Retrieved from www.ft.com.

Asian Infrastructure Investment Bank. (2016, February 5) Asian Infrastructure Investment Bank appoints 5 Vice-Presidents. Retrieved from www.aiib.org.

Asian Infrastructure Investment Bank. (2017, July 18). AllB receives third triple-A credit rating. Retrieved from www.aiib.org.

Australia Prime Minister and Cabinet. (2015, March 29). Asian Infrastructure Investment Bank. Retrieved from pmtranscripts.pmc.gov.au/release/transcript-24327

Australia Treasury (2015, June 24). Australia to join the Asian Infrastructure Investment Bank. Retrieved from jbh.ministers.treasury.gov.au.

Breslin, S. (2013). China and the global order: Signalling threat or friendship? International Affairs, 89(3), 615-634.

Breslin, S. (2018). Global reordering and China's rise: Adoption, adaptation and reform. The International Spectator, 53(1), 57-75.

Brüggemann, M. (2014). Between frame setting and frame sending: How journalists contribute to news frames. Communication Theory, 24(1), 61-82.

Cai, K. G. (2018) The one belt one road and the Asian infrastructure investment bank: Beijing's new strategy of geoeconomics and geopolitics. Journal of Contemporary China, doi.org/10.1080/10670564.2018.1488101

Callaghan, M., \& Hubbard, P. (2016). The Asian Infrastructure Investment Bank: Multilateralism on the Silk Road. China Economic Journal, 9(2), 116-139.

Chan, L. H. (2017) Soft balancing against the US pivot to Asia: China's geostrategic rationale for establishing the Asian Infrastructure Investment Bank. Australian Journal of International Affairs, 71(6), 568-590.

Chen, W. (2015, March 27). US about-face on AllB would be welcomed. China Daily. Retrieved from www.chinadaily.com.cn.

Chin, G. T. (2016). Asian Infrastructure Investment Bank: Governance innovation and prospects. Global Governance, 22(1), 11-25.

China Daily. (2014, March 7). Wheels in motion for new Asian investment bank. Retrieved from www.chinadaily.com.cn.

Chong, D., \& Druckman, J. N. (2007). Framing theory. Annual Review of Political Science, 10(1), 103-126.

D'Angelo, P. (2002). News framing as a multiparadigmatic research program: A response to Entman. Journal of Communication, 52(4), 870-888.

D'Angelo, P., \& Kuypers, J. A. (Eds.). (2010). Doing news framing analysis: Empirical and theoretical perspectives. New York, NY: Routledge.

De Jonge, A. (2017). Perspectives on the emerging role of the Asian Infrastructure Investment Bank. International Affairs, 93(5), 1061-1084.

Denyer, S. (2015, June 20). China launches development bank for Asia, calling it step in 'epic journey'. Washington Post. Retrieved from www.washingtonpost.com.

De Vreese, C. H. 2005. News framing: Theory and typology. Information Design Journal \& Document Design, 13, 51-62.

Donnan, S. (2015, September 27). White House declares truce with China over AllB. Financial Times. Retrieved from www.ft.com.

Drezner, D. (2015, March 27). Anatomy of a whole-of-government foreign policy failure. Washington Post. Retrieved from www.washingtonpost.com.

Entman, R. (1993). Framing: Toward clarification of a fractured paradigm. Journal of Communication, 43(4), 51-58.

Etzioni, A. (2016). The Asian Infrastructure Investment Bank: A case study of multifaceted containment. Asian Perspective, 40(2), 173-196. 
Evans-Pritchard, A. (2015, March 25). US risks epic blunder by treating China as an economic enemy. The Telegraph. Retrieved from www.telegraph.co.uk.

Fackler, M. (2015, March 31). Japan, sticking with US, says it won't join China-led bank. New York Times. Retrieved from www.nytimes.com.

Feldman, N. (2015, April 2). AllB: Chinese cash versus American might. Japan Times. Retrieved from www.japantimes.co.jp.

Financial Times (2015, May 20). America's flawed strategy towards AllB. Retrieved from www.ft.com.

Financial Times (2016, March 22). China plays ball with its development lending. Retrieved from www.ft.com.

Fu, J. (2016, January 27). AllB chief rules out China veto. China Daily. Retrieved from www.chinadaily.com.cn.

Fu, J. (2017, July 5). Three major challenges AllB must overcome. China Daily. Retrieved from www.chinadaily.com.cn.

Funabashi, Y. (2014, December 9) A futile boycott of China's bank will not push Xi out of his back yard. Financial Times. Retrieved from www.ft.com.

Gamson, W. A. (1988). The 1987 distinguished lecture: A constructionist approach to mass media and public opinion. Symbolic Interaction, 11(2), 161-174.

Gamson, W. A., \& Modigliani, A. (1989). Media discourse and public opinion on nuclear power: A constructionist approach. American Journal of Sociology, 95(1), 1-37.

Gitlin, T. (1980). The whole world is watching: Mass media in the making and unmaking of the new left. Berkeley, CA: University of California Press.

Gu, B. (2017). MDBs' accountability mechanism: a perspective of AllB. Journal of World Trade, 51(3), 409-423.

Hameiri, S., \& Jones, L. (2018). China challenges global governance? Chinese international development finance and the AllB. International Affairs, 94(3), 573-593.

Hecan, M. (2016). Dynamics of institutional proliferation in financing for development: The birth of the AllB. Development, 59, 158-166.

Higgins, A., \& Sanger D. (2015, March 17). 3 European powers say they will Join China-led bank. New York Times. Retrieved from www.nytimes.com.

Hornby, L. (2015, April 13). China rejects Taiwan as AllB founding member. Financial Times. Retrieved from www.ft.com.

Hsu, J. W. (2015, April 13). China thwarts Taiwan's bid to be founding member of AllB. Wall Street Journal. Retrieved from www.wsj.com.

Humphrey, C. (2015). Developmental revolution or Bretton Woods Revisited: The prospects of the BRICS New Bank and the Asian Infrastructure Investment Bank. London, UK: Overseas Development Institute.

Ikenberry, G. J., \& Lim, D. (2017). China's emerging Institutional statecraft: The Asian Infrastructure Investment Bank and the prospects for counter-hegemony. Washington, DC: Brookings Institution.

Japan Times (2015a, April 8) Japan still on fence about AllB but envisages $\$ 1.5$ billion contribution if it joins. Retrieved from www.japantimes.co.jp.

Japan Times (2015b, April 20) Why Japan won't join the AllB. Retrieved from www. japantimes.co.jp.

Japanese Foreign Ministry (2015, April 9) Press conference by State Minister Kiuchi Minoru. Retrieved from www.mofa.go.jp.

Jin, L. Q. (2017, June 16) Opening address at meeting of the AllB Board of Governors. Retrieved from www.aiib.org.

Johnston, A.I. (2003). Is China a status quo power? International Security, 27(4), 5-56. 
Kahler, M. (2017). Regional challenges to global governance. Global Policy, 8(1), 97-100.

Kawai, M. (2015) Asian Infrastructure Investment Bank in the evolving international financial order. In D. Bob (Ed.), Asian Infrastructure Investment Bank: China as responsible stakeholder? (pp. 5-26). Washington, DC .: Sasakawa Peace Foundation USA.

Khan, M. (2015, April 11). How China grew desperate to conceal its power from the world. The Telegraph. Retrieved from www.telegraph.co.uk.

Kim, A., \& Kim, J. (2018). China's aggressive 'periphery diplomacy' and South Korean perspectives. The Pacific Review, 31(2), 267-277.

Kim, J. (2017, June 17). AllB chief tries to distance bank from Xi Jinping. Nikkei Asian Review. Retrieved from www.asia.nikkei.com.

Kim, J. Y. (2015, June 8). Welcoming AllB to fight poverty. Retrieved from www. worldbank.org/.

Kynge, J. (2017, May 3). AllB chief unveils aim to rival lenders such as ADB and World Bank. Financial Times. Retrieved from www.ft.com.

Lagarde, C. (2015, April 16). Transcript of a press briefing with the IMF Managing Director. Retrieved from www.imf.org.

Lawrence, R. G. (2000). Game-framing the issues: Tracking the strategy frame in public policy news. Political Communication, 17(2), 93-114.

Li, X. (2016, June 1). AllB 'set to earn international trust, credibility'. China Daily. Retrieved from www.chinadaily.com.cn.

Liao, R. (2015, 27 July). Out of the Bretton Woods: how the AllB is different. Foreign Affairs. Retrieved from www.foreignaffairs.com.

Lou, J. W. (2015, June 25). Inclusive AllB can make a difference. China Daily. Retrieved from www.chinadaily.com.cn.

Magnier, M. (2015, June 29). AllB tests Beijing's management style. Wall Street Journal. Retrieved from www.wsj.com.

Malkin, A., \& Momani, B. (2016). An effective Asian Infrastructure Investment Bank: a bottom up approach. Global Policy, 7(4), 521-530.

Massola, J. (2015, March 25). Tony Abbott and Joe Hockey say \$100b China bank decision within days. Sydney Morning Herald. Retrieved from www.smh.com.au.

Mearsheimer, J.J. (2010). The gathering storm: China's challenge to US power in Asia. The Chinese Journal of International Politics, 3(4), 381-396.

Menegazzi, S. (2017). Global economic governance between China and the EU: The case of the Asian Infrastructure Investment Bank. Asia Europe Journal, 15(2), 229-242.

New York Times (2015, March 20). US allies lured by China's bank. Retrieved from www.nytimes.com.

Nikkei Asian Review (2015a, March 26). ADB chief sees possible joint financing with China-led AllB. Retrieved from asia.nikkei.com.

Nikkei Asian Review (2015b, August 11). Would-be borrowers demand affordable AllB loans. Retrieved from asia.nikkei.com.

Nussey, S. (2016, May 12). Asia's development banks talk up cooperation, jostle for dominance. Nikkei Asian Review. Retrieved from asia.nikkei.com.

Pan, Z. D., \& Kosicki, G.M. (1993). Framing analysis: An approach to news discourse. Political Communication, 10(1), 55-75.

Pennington, M. (2015, March 27). US isolated as allies line up to join China-led bank. Washington Post. Retrieved from www.washingtonpost.com.

Perlez, J. (2014, October 10). US balks at Beijing's development bank plans. New York Times. Retrieved from www.nytimes.com. 
Perlez, J. (2015, March 20). As Beijing builds bank Washington is left behind. New York Times. Retrieved from www.nytimes.com.

Piling, D. (2015, May 27). A bank made in China and better than the Western model. Financial Times. Retrieved from www.ft.com.

Prasad, R. (2018, April 21). EU ambassadors condemn China's Belt and Road Initiative. The Diplomate. Retrieved from thediplomat.com.

Reese, S. D. (2001) Introduction. In S.D. Reese, O.H. Gandy, \& A.E. Grant (Eds.), Framing public life: Perspectives on media and our understanding of the social world (pp. 1-31). Mahwah, NJ: Erlbaum.

Reisen, $\mathrm{H}$. (2015). Will the AllB and the NDB help reform multilateral development banking? Global Policy, 6(3), 297-304.

Ren, X. (2015). A reform-minded status quo power? China, the G20, and reform of the international financial system. Third World Quarterly, 36(11), 2023-2043.

Ren, X. (2016) China as an institution-builder: The case of the AllB. The Pacific Review, 29(3), 435-442.

Seawright, J., \& Gerring, J. (2008). Case selection techniques in case study research: A menu of qualitative and quantitative options. Political Research Quarterly, 61(2), 294-308.

Semetko, H. A., \& Valkenburg, P. M. (2000). Framing European politics: A content analysis of press and television news. Journal of Communication, 50(2), 93-109.

Singapore Ministry of Finance (2014, October 24). Deputy Prime Minister and Minster for Finance Mr Tharman Shanmugaratnam signs MoU on Establishing the Asian Infrastructure Investment Bank. Retrieved from www.mof.gov.sg.

Singapore Ministry of Finance (2015a, June 29). Singapore signs Asian Infrastructure Investment Bank Articles of Agreement. Retrieved from www.mof.gov.sg.

Singapore Ministry of Finance (2015b, August 17). Second Reading Speech by Mrs Josephine Teo, Senior Minister of State for Finance and Transport, for the Asian Infrastructure Investment Bank Act 2015. Retrieved from www.mof.gov.sg.

Strand, J.R., Flores, E.M., \& Trevathan, M.W. (2016). China's leadership in global economic governance and the creation of the Asian Infrastructure Investment Bank. Rising Powers Quarterly, 1(1), 55-69.

Strauss, A., \& Corbin, J. M. (1990). Basics of qualitative research: Grounded theory procedures and techniques. Thousand Oaks, CA: Sage Publications.

Subacchi, P. (2015, March 31). The AllB is a threat to global economic governance. Foreign Policy. Retrieved from foreignpolicy.com.

Sun, Yun (2015). China and the evolving Asian Infrastructure Investment Bank. In D. Bob (Ed.), Asian Infrastructure Investment Bank: China as responsible stakeholder? (pp. 27-41). Washington, DC: Sasakawa Peace Foundation USA.

Tsui, E. (2015, January 20). Former Thai foreign minister attacks China-led lender. Nikkei Asian Review. Retrieved from asia.nikkei.com.

UK Treasury (2015a, March 21). UK announces plans to join Asian Infrastructure Investment Bank. Retrieved from www.gov.uk/government/organisations/hm-treasury.

UK Treasury (2015b, June 29). UK signs founding Articles of Agreement of the Asian Infrastructure Investment Bank. Retrieved from www.gov.uk/government/ organisations/hm-treasury.

UK Treasury (2015c, December 3). UK ratifies articles of agreement of the Asian Infrastructure Investment Bank. Retrieved from www.gov.uk/government/ organisations/hm-treasury.

US Treasury (2015a, March 19). Secretary Lew's hearing on the international financial system. Retrieved from www.treasury.gov. 
US Treasury (2015b, 29 April). Remarks by Under-Secretary Nathan Sheets at the Center for Strategic \& International Studies. Retrieved from www.treasury.gov.

Van Gorp, B. (2005). Where is the frame? Victims and intruders in the Belgian press coverage of the asylum issue. European Journal of Communication, 20(4), 484-507.

Van Gorp, B. (2007). The constructionist approach to framing: Bringing culture back in. Journal of Communication, 57(1), 60-78.

Van Gorp, B. (2010). Strategies to take subjectivity out of framing analysis. In P. D'Angelo \& J.M. Kuypers (Eds.), Doing news framing analysis: Empirical and theoretical perspectives (pp. 84-109). New York, NY: Routledge.

Voeten, E. (2015). Why the US effort to curb the Asian Infrastructure Investment Bank is doomed to fail (and why it doesn't matter all that much). Washington Post. Retrieved from www.washingtonpost.com.

Wan, M. (2016). The Asian Infrastructure Investment Bank: The construction of power and the struggle for the East Asian international order. New York, NY: Palgrave Macmillan.

Wang, H. (2017). New multilateral development banks: Opportunities and challenges for global governance. Global Policy, 8(1), 113-118.

Washington Post (2015, March 22). China's new development bank bodes poorly for the US. Retrieved from www.washingtonpost.com.

Weaver, C. (2015). The rise of China: Continuity or change in the global governance of development? Ethics \& International Affairs, 29(4), 419-431.

Wessler, H., Wozniak, A., Hofer, L., \& Lück, J. (2016). Global multimodal news frames on climate change: A comparison of five democracies around the world. The International Journal of Press/Politics, 21(4), 423-445.

Weyer, M. V. (2015, March 14). Shouting at the Chinese is not in our interest. The Telegraph. Retrieved from www.telegraph.co.uk.

Wilson, J.D. (2017). The evolution of China's Asian Infrastructure Investment Bank: From a revisionist to status-seeking agenda. International Relations of the Asia-Pacific.

Wu, D. (2015, March 28). Nationalists keen on China's new regional bank. Retrieved from asia.nikkei.com.

Xi, J. P. (2016, January 16). Full text of Chinese President Xi Jinping's address at AllB inauguration ceremony. Retrieved from http://www.xinhuanet.com/english.

Yang, G. (2015, April 7). AllB to help West grasp China's ideals. China Daily. Retrieved from www.chinadaily.com.cn.

Yang, H. (2016). The Asian Infrastructure Investment Bank and Status-Seeking: China's Foray into Global Economic Governance. Chinese Political Science Review, 1(4), 754-778.

Yu, H. (2017). Motivation behind China's 'one belt, one road' initiatives and establishment of the Asian Infrastructure Investment Bank. Journal of Contemporary China, 26(105), 353-368.

Zhang, F. (2017). Holism Failure: China's inconsistent stances and consistent interests in global financial governance. Journal of Contemporary China, 26(105), 369-384.

Zhang, Z. (2016, January 12). Inclusive AllB to boost sustainable growth. China Daily. Retrieved from www.chinadaily.com.cn.

Zheng, C., \& Liu, Y. (2018). Strategic reassurance in institutional contests: Explaining China's creation of the Asian Infrastructure Investment Bank. Journal of Contemporary China, doi.org/10.1080/10670564.2018.1488098

Zheng, Y. (2016, January 4). Investment bank AllB to begin operating in mid-January. The Telegraph. Retrieved from www.telegraph.co.uk. 


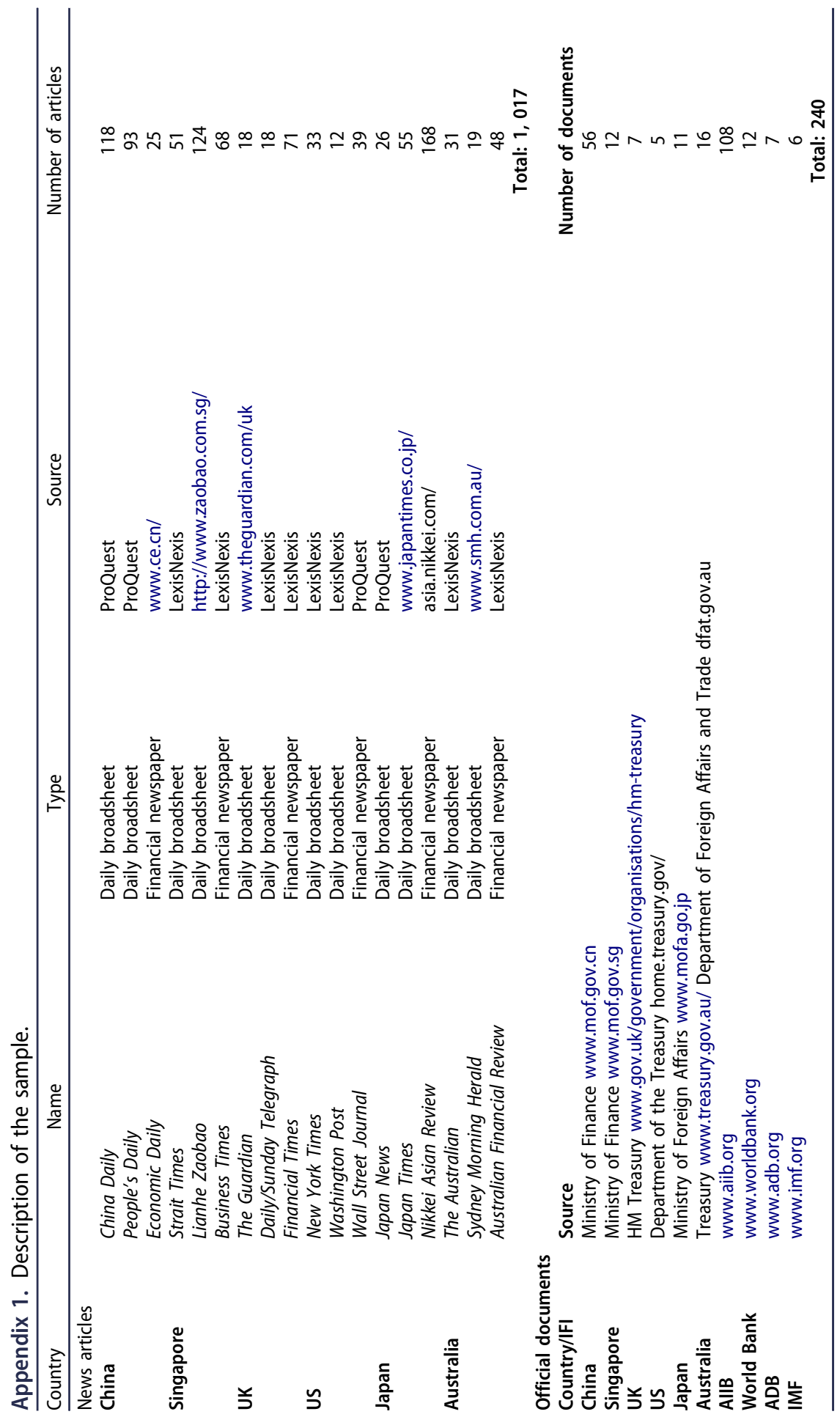




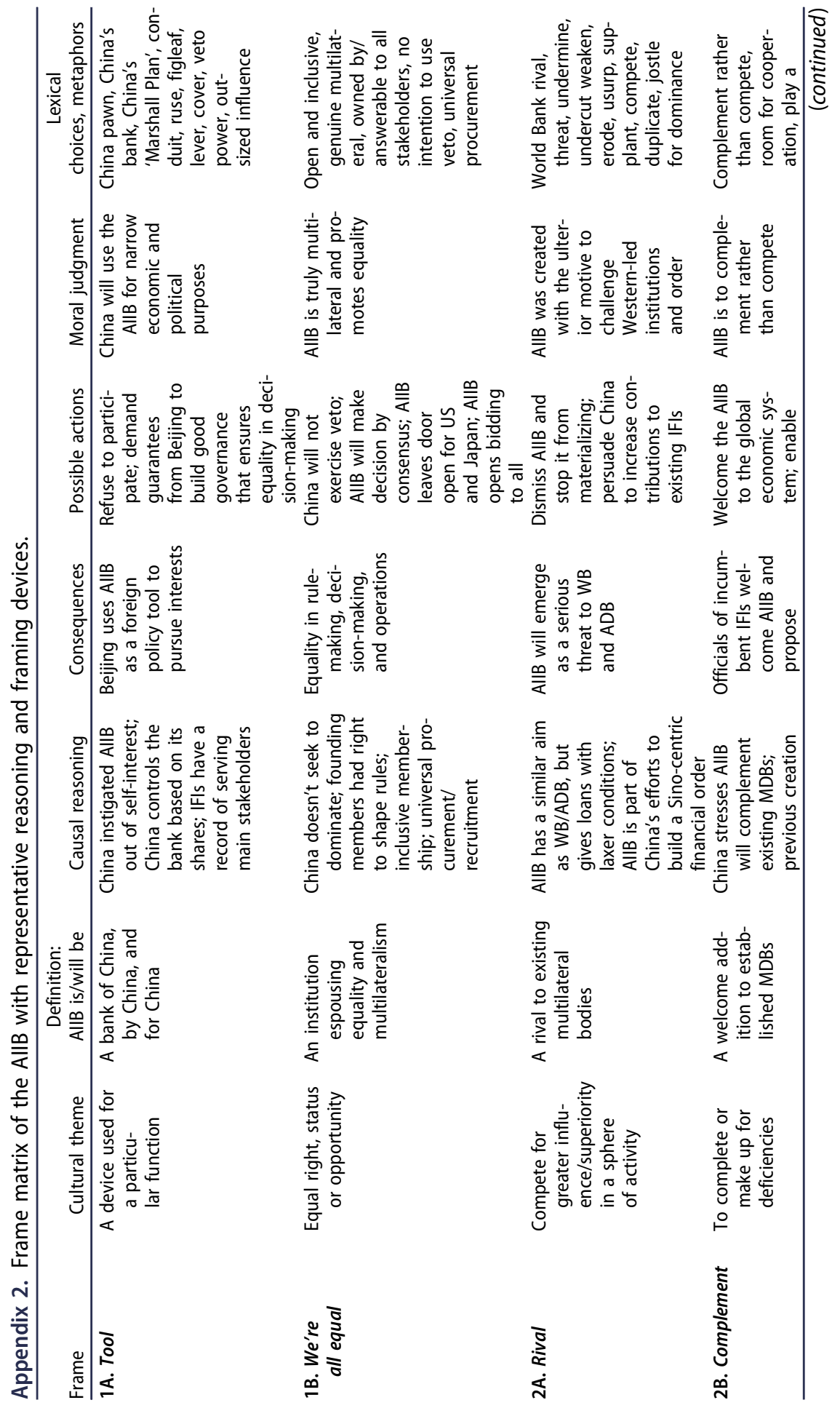




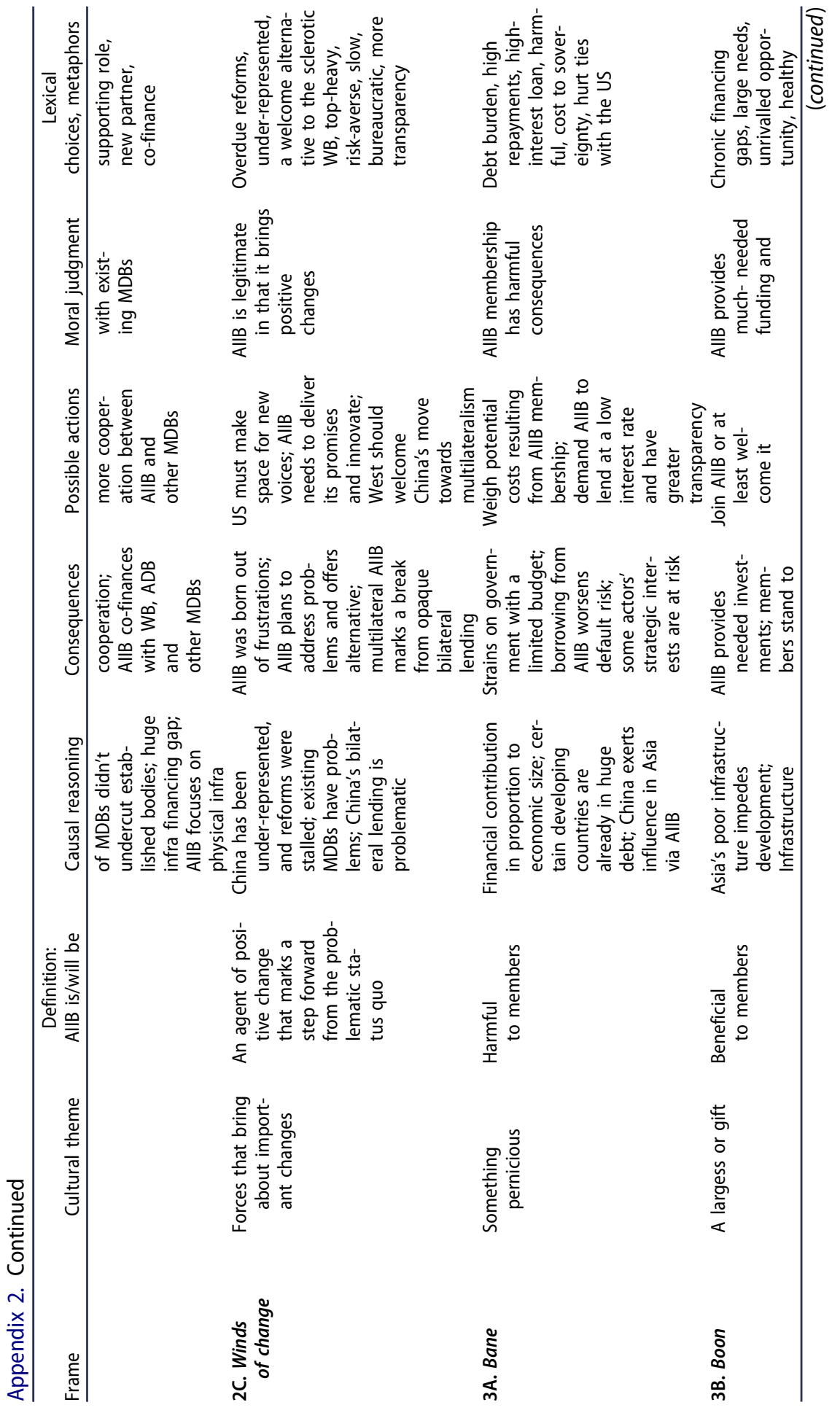




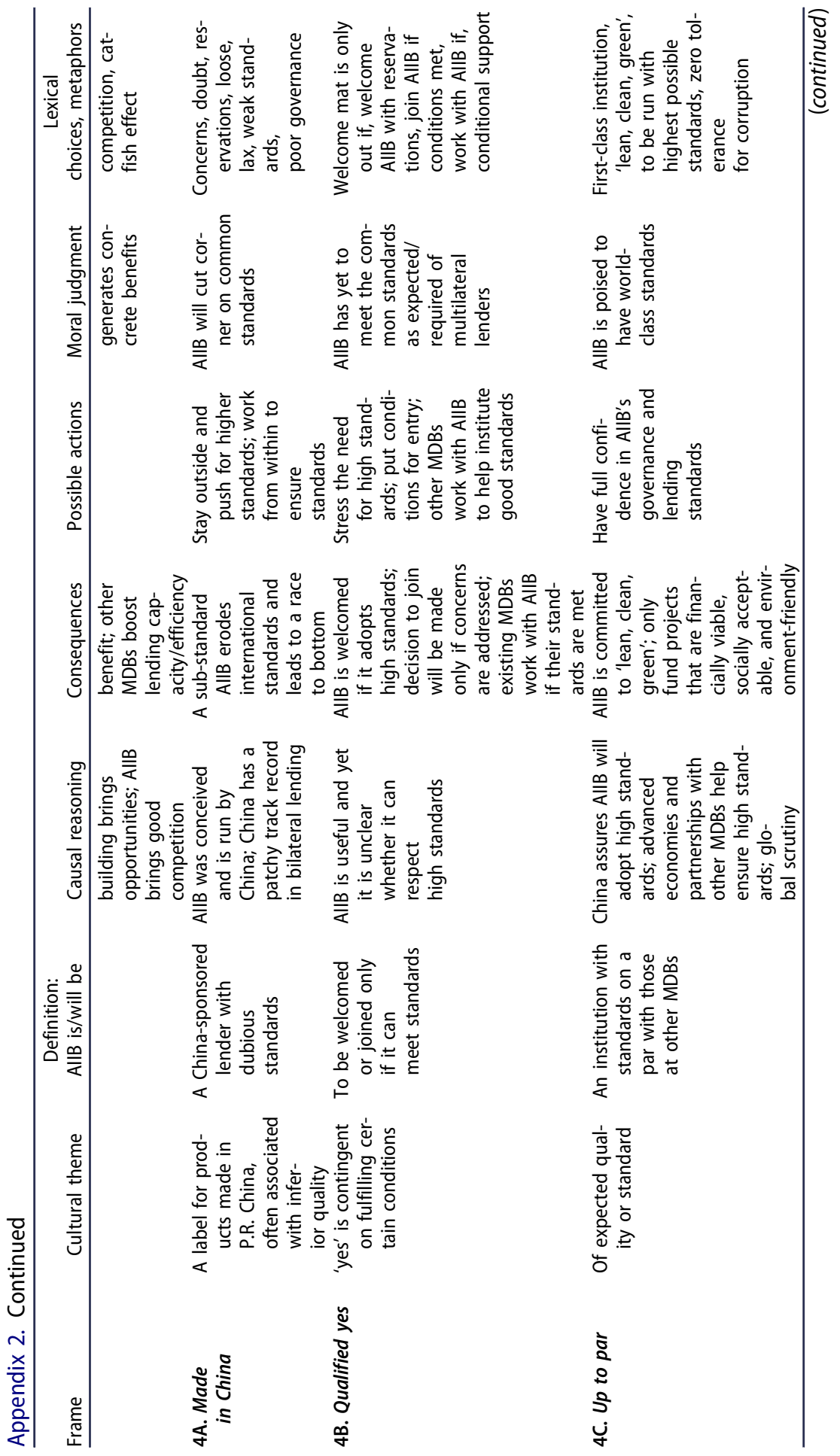




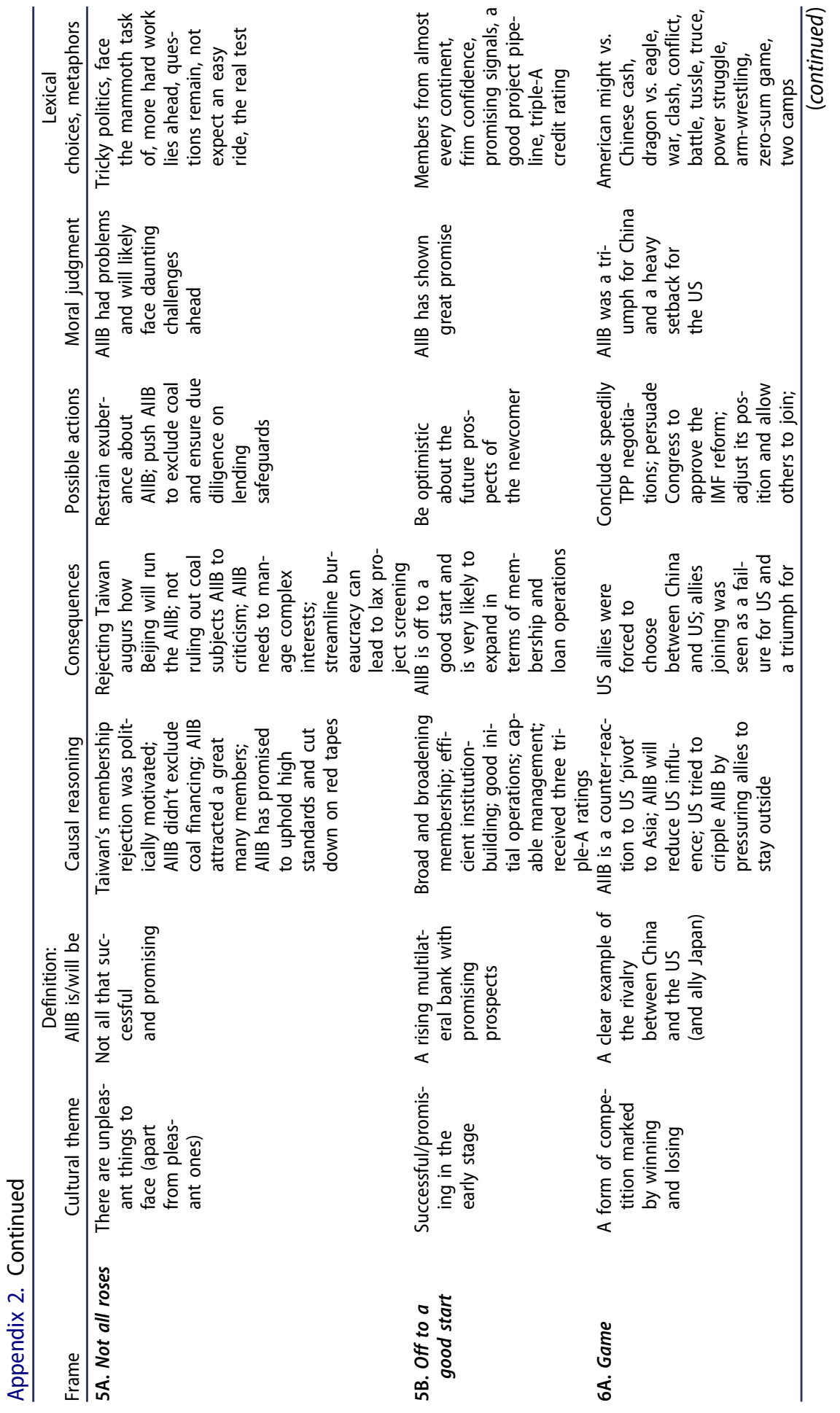




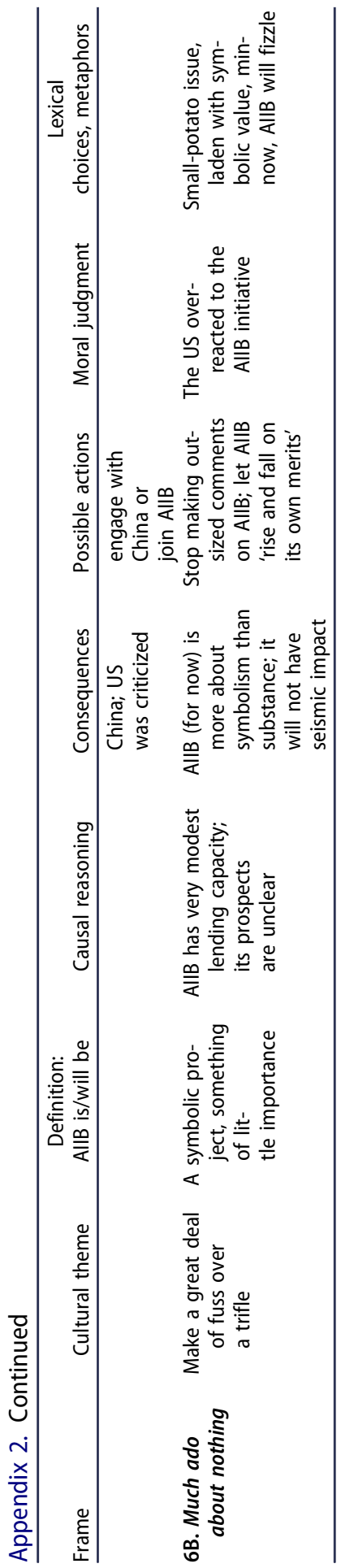

